\title{
Potentials of phototrophic bacteria in treating pharmaceutical wastewater
}

\author{
${ }^{*}$ E. I. Madukasi; X. Dai; C. He; J. Zhou \\ State Key Laboratory of Urban Water Resource and Environment, Harbin Institute of Technology, 202 Haihe Road \\ Harbin, Nangang district, Harbin 150090, P R China \\ Received 9 May 2009; $\quad$ revised 25 July 2009; accepted 5 November 2009; available online 1 December 2009
}

\begin{abstract}
A suspended growth photobioreactor was utilized to treat pharmaceutical wastewater by a wild strain purple non-sulfur photosynthetic bacterium isolated from the soil. The strain was named Z08 and identified as Rhodobacter-sphaeroides by $16 \mathrm{SrDN}$. The photobioreactor was illuminated externally with two (40 W) fluorescent compact light sources on both sides. Its operation $\mathrm{pH}$ and temperature were between $6.8-7.0$ and $20-30{ }^{\circ} \mathrm{C}$, respectively. Optimum growth of the isolate was obtained after enrichment of the pharmaceutical wastewater with $0.5 \%$ ammonium sulfate and $0.1 \%$ yeast extract under microaerobic optimum light (6000 lx) condition at $5 \mathrm{~d}$ retention. Using these optimum conditions, the maximum dry cell weight and chemical oxygen demand percentage removal were $880 \mathrm{mg} / \mathrm{L}$ and $80 \%$. Chemical analysis of the culture after treatment of the enriched and non-enriched wastewater showed the crude protein content of the biomass to be $54.6 \%$ and $38.0 \%$, respectively. This study proved that photosynthetic bacteria could transform complex wastewater that contains recalcitrant organic compounds with a resultant recovery of useful products.
\end{abstract}

Keywords: Biotreatment; Microaerobic light; Photosynthetic bacteria; Purple non sulfur bacteria; Static light exposure reactor

\section{INTRODUCTION}

Characteristics of the pharmaceutical industries are the diversity of their process operations, which gives rise to a wide variation in the liquid wastes. There is little similarity between effluents from different factories and individual effluents may differ continually as a result of process changes. In many cases, these effluents contain little or no biodegradable organic matters and the pollutant loads in terms of biological oxygen demand (BOD) may be negligible hence higher chemical oxygen demand (COD) than BOD (Bitton, 口DD Huseyin et al., 2006). Most substances found in a pharmaceutical industrial wastewater are structurally complex organic chemicals that are resistant to biological degradation (Cokgor et al., $\mathrm{WD}$ Ren et al, 2008), thus the need for segregation and collection of particularly toxic materials in a conventional biological treatment of pharmaceutical industrial wastewater (Gallely et al., 1977).

Conventional biological treatment methods are usually inappropriate for the treatment of pharmaceutical wastewaters because of the negligible \*Corresponding Author Email: madify2002@yahoo.com Tel./Fax: +8615 846385628
BOD content of the wastewater. For instance, the wastewater for this study has a BOD of $146 \mathrm{mg} / \mathrm{L}$ and COD of about $8000 \mathrm{mg} / \mathrm{L}$, resulting in the BOD/COD ratio of about 0.02 . Hence, the need to try a novel biological treatment method which is the application of purple non-sulfur photosynthetic bacteria (PNSB) in degrading pollutants found in the pharmaceutical wastewater.

PNSB are widely distributed in the ocean, lakes, rivers, soil and activated sludge also in high temperature, low-temperature, low-salt, high-salt environment. They grow in both microaerobic and anaerobic light conditions while utilizing various substrates as sources of carbon and energy with ammonium and /or nitrate as a source of nitrogen and may also use sulphide or thiosulphate as an electron donor under photosynthetic conditions (Imhoff and Trüper, 1 100 Kantachote et al., 2005). They are metabolically the most versatile among all prokaryotes; anaerobically photoautotrophic and hotoheterotrophic in the light or microaerobic light condition (Holt et al., 1994). Photosynthetic bacteria B) for wastewater 
treatment has generally proven to be a cost effective system for treating wastewater. This is because PSB does not only produce quality effluent, but produces substances of commercial interest such as single cell protein (SCP), biopolymers, antimicrobial agents and therapeutic compounds etc (Bertling et al., 2006; Lorrungruang et al., 2006 ).

Due to these properties, PNSB have been utilized by other researchers to treat different types of wastewaters such as concentrated latex wastewater (Choorit et al., 2002), odorous swine wastewater (Myung et al., 2004), tuna condensate (Prasertsan et al., 1997), oil-containing sewage wastewater (Takeno et al., 2005) and latex rubber sheet wastewater (Kantachote et al., 2005). Kasomu and Obst (2009) studied the influence of photosynthesis on calcite precipitation.

The main aims of this study are to isolate, identify and test the ability of wild strain PNSB as well as to determine the optimum conditions for this isolate to be most effective in treating pharmaceutical wastewater. There could be another advantage in utilizing this PNSB to treat pharmaceutical wastewater because the biomass of PNSB has been reported to be a source of SCP production and could be used as an alternative to manure, fish feed, or agricultural supplement as it is rich in protein and vitamins (Getha et al., 1998; Banerjee et al., 2000; Kantachote et al., 2005), hence the harvested biomass from the treatment will be analytically evaluated to ascertain it's suitability as a nutritional supplement.

This research was carried out between March 2008 and March 2009 at the School of Municipal and Environmental Engineering Department of Harbin Institute of Technology, China.

\section{MATERIALS AND METHODS}

Bacterium and culture

\section{PNSB isolation}

A purple non-sulfur bacterium named Z08 and isolated from soil was used to treat pharmaceutical wastewater. The bacterium was isolated with Sistrom minimal medium (RCVBN) (Eloi et al., 1992) consisting of (in g/L) DL-malate: (4). $\mathrm{MgSO}_{4}:(0.12)$. $\left(\mathrm{NH}_{4}\right)_{2} \mathrm{SO}_{4}$ : (1). $\mathrm{CaCl}_{2}$ : (0.075). $\mathrm{KH}_{2} \mathrm{PO}_{3}$ : (0.3). $\mathrm{Na}_{2}$ EDTA: (0.020). $\mathrm{VB}_{1:}(0.001)$. Nicotinic acid: (0.001). Biotin: (0.015). Trace element solution, $1 \mathrm{~mL}$. The trace element solution contained (in mg/L) Zn SO $4.7 \mathrm{H}_{2} \mathrm{O}$ : (20). $\mathrm{MnCl}_{2} \cdot 4 \mathrm{H}_{2} \mathrm{O}$ : (6). $\mathrm{H}_{3} \mathrm{BO}_{3}$ : (60). $\mathrm{CoCl}_{2} \cdot 6 \mathrm{H}_{2} \mathrm{O}:(40) \cdot \mathrm{CuCl}_{2} \cdot 2 \mathrm{H}_{2} \mathrm{O}:(2)$.
$\mathrm{Na}_{2} \mathrm{MoO}_{4}$ : (6). $2 \mathrm{~g}$ of soil was added to $95 \mathrm{~mL}$ sterile medium and incubated anaerobically at 28-35 ${ }^{\circ} \mathrm{C}$ depending on the ambient temperature for about $96 \mathrm{hrs}$ under illumination with a $100 \mathrm{~W}$ incandescent lamp. Anaerobic condition was created by addition of $5 \mathrm{ml}$ sterile liquid paraffin on top of the solution in the test tube. Purification of single colonies was achieved by successive re-streaking on the RCVBN medium containing $1.5 \%$ agar and incubated at the same condition. The initial $\mathrm{pH}$ of the medium was adjusted to 6.8 by $5 \mathrm{M} \mathrm{NaOH}$.

\section{Bacterial identification}

The isolate was characterized using both morphological and physiological properties and according to Bergey's manual of systematic bacteriology (Imhoff and Trüper, 1989) and Bergey’s manual of determinative bacteriology (Holt et al., 1994).

Isolation and identification of bacteriochlorophylls

Bacteriochlorophylls were isolated, characterized and identified as described by Oelze (Okubo, et al, 2006). The isolated bacteria spectra were obtained with an Aminco DW-200 UV-Visible spectrometer in the split mode.

\section{Cellular fatty acids analysis}

Photosynthetic isolates were cultured on bactotryptic soy broth agar (Difco) and incubated at $28{ }^{\circ} \mathrm{C}$ for $48 \mathrm{~h}$, the cellular fatty acids contents were determined using the MIDI procedure (MIDI, Inc, New York Del). Identification of the isolates were based on a comparison of fatty acid profiles using the fatty acid profiles in tryptic soy broth agar anaerobe database (Sasser, 1990).

\section{Inoculums production}

The inoculums were prepared by growing the cells in a modified Sistrom's minimal malate medium (pH6.8) microaerobically in a reciprocating thermostatic shaker (unitron, Infors AG, Germany) at $200 \mathrm{rpm}$ for $48 \mathrm{~h}$ with a temperature range of $28-30^{\circ} \mathrm{C}$. Ammonium sulfate ( 0.99 $\mathrm{g} / \mathrm{L})$ and malate $(4.02 \mathrm{~g} / \mathrm{L})$ were used as sources of nitrogen and carbon, respectively. Sterilization of the medium, photobioreactor and wastewater-test-media were accomplished by autoclaving at $121^{\circ} \mathrm{C}$ for $15 \mathrm{~min}$, inoculation into the medium or bioreactor was as $10 \%$ $\mathrm{v} / \mathrm{v}$ inoculums from a culture growing in the modified RCVBN medium. For use as an inoculums, cell 
suspension was adjusted to the desired optical density (0.500) at $660 \mathrm{~nm}$ using the sterile RCVBN medium as diluents. The sterile RCVBN medium was also used as the blank.

\section{Wastewater}

Wastewater from a pharmaceutical company located in Harbin, Heilongjiang province, China was collected at different times from the company's holding tank, each collection was analyzed for COD, BOD, suspended solids (SS), total dissolved solids (TDS) and $\mathrm{pH}$. The properties of the wastewater varied at each collection time, hence representative wastewater sample was centrifuged at $4000 \mathrm{rpm}$ for $10 \mathrm{~min}$ followed by autoclaving at $121^{\circ} \mathrm{C}$ for $15 \mathrm{~min}$ to achieve sterile condition prior to use as the growth medium. It is imperative that autoclaving could cause volatilization of fatty acids and $\mathrm{H}_{2} \mathrm{~S}$ as the Teflon screw cap was at that stage loosely closed and this apparently would affect both the COD and BOD values. For this reason, the COD and BOD values reported in this study were determined after centrifugation and autoclaving of the raw wastewater. The original pharmaceutical wastewater without any pretreatment (centrifugation/ autoclaving) had COD and BOD values of 9450 and $197 \mathrm{mg} / \mathrm{L}$, respectively.

\section{Optimization of wastewater composition and treatment conditions}

Effect of added nitrogen source, ammonium or nitrate were added to the sterilized wastewater (SW) medium at varied concentrations of $0,0.1,0.2,0.3$ and $0.4 \%$. The wastewater $\mathrm{pH}$ of 6.6 was not adjusted as the optimum $\mathrm{pH}$ for growing most bacteria is in the range of 6.5-7.5 (Bitton, 2005; Cheremisinoff, 1996). Ammonium being the best nitrogen source was tested again at higher concentrations of 0 0.5, 0.75, 1.0 and $1.5 \%$ respectively. In most cases SW medium was used under microaerobic light (3500 lx) for $72 \mathrm{~h}$.

SW medium supplemented with optimal concentration $(0.5 \%)$ of ammonium was used as the base control to evaluate the effect of added yeast extract (YE). Yeast extract is a complex natural material with high vitamin B level; it was tested for its effect on growth at the following concentrations; $0,0.01,0.05,0.1,0.2$, $0.3 \%$. All the cultivations were grown three consecutive times for 72 hrs under microaerobic light conditions.

The effect of light intensity variation was investigated by growing the isolate in sterilized optimized wastewater (SOW); i.e. the wastewater was supplemented with $0.5 \%\left(\mathrm{NH}_{4}\right)_{2} \mathrm{SO}_{4}$ and $0.1 \%$ yeast extract, grown under light intensities of 500, 1000, 2000, 4000, 6000 and 8000 lumens, respectively. These variations were obtained by adjusting the distances between light sources and the reactor tubes. In all these, the temperature variation was same $\left(20-31^{\circ} \mathrm{C}\right)$.

\section{Photobioreactor}

A test tube of $100 \mathrm{~mL}$ with cellophane tapered edge to prevent volatilization was used as a bioreactor. Three treatments were set as follows: (SOW) as a control without inoculums; SOW plus $10 \%$ inoculums and SW plus $10 \%$ inoculums. The photobioreactor temperature was between $20-31^{\circ} \mathrm{C}$ depending on the ambient temperature. Illumination was with $40 \mathrm{~W}$ compact fluorescent lamps at the desired lumens on both sides of the bioreactor. Cell growth, $\mathrm{pH}$ and COD were monitored at the end of each retention time of 3, 5 and 7 days of cultivation, respectively. Microaerobic condition was achieved by creating a head space in the PBR, no flushing with either argon or nitrogen gases and the cultivation condition was static-light exposure. The dissolved oxygen (DO) levels of all treatment were between $0.7-1.63 \mathrm{mg} / \mathrm{L}$.

\section{Analytical methods}

The incident light intensity was measured by a TES1330A digital light meter, while the functional groups were determined with GC-FTIR. Organic compounds in the wastewater were identified qualitatively using gas chromatography coupled with mass spectrometry (GC-MS). Instrumentation was a Hewlett packard (HP) 5890 Series II gas chromatograph, interfaced with a HP Chem-Station data system and linked to a HP 5972 mass selective detector operated in scan mode. Results are reported as lists of those compounds reliably and tentatively identified. It meant that the organic compounds identification were carried out by computer matching against a HPWiley 275 library of 275,000 mass spectra combined with expert interpretation and that the identified compounds were not confirmed against their standard compounds because of the inability to get the standard compounds during the time of the experiment.

For the determination of the parameters, the cell suspensions were centrifuged at $4000 \mathrm{rpm}$ for $20 \mathrm{~min}$ and cell pellets were used for the determination of dry cell weight and crude protein. The supernatant was 
used for COD, organic compounds, SS and $\mathrm{pH}$ determinations. The bacterial cell concentration was determined by optical density at $660 \mathrm{~nm}$ (i.e. $\mathrm{OD}_{660}$ ) using a UV-VIS spectrophotometer (Shimadzu UV-120). The cell dry weights were determined by centrifuging $10 \mathrm{~mL}$ aliquots of culture at $4000 \mathrm{rpm}$ for $20 \mathrm{~min}$ and the cell pellets were washed properly with distilled water then filtered using $0.45 \mu \mathrm{m}$ pore size, $47 \mathrm{~mm}$ in diameter membrane filter paper to remove salts and non-cellular materials. Each loaded filter was dried at $105^{\circ} \mathrm{C}$ until the weight was invariant (about $72 \mathrm{~h}$ ). The dry weight of the blank filter was subtracted from that of the loaded filter to obtain the dry cell weight (DCW). The $\mathrm{OD}_{660}$ value was converted to DCW concentration via proper calibration, (where $1.0 \mathrm{OD}_{660}$ approximately equals $0.6 \mathrm{~g}$ dry cell/L.).

Crude protein was expressed as percentage total nitrogen $(\% \mathrm{~N})$ multiplied by 6.25 . TDS, SS, BOD, COD and $\mathrm{pH}$ were measured according to standard methods (APHA, 1992). It is worthy to mention that the COD values quoted in this study were measured after centrifugation and sterilization of the wastewater by autoclaving. Trace metals were measured using a Perkin Elmer Optima 5300DV ICP aided by a WTW microwave digester (WTW is a supplier name that deals on electrochemistry instruments just like Hach or YSI). Organic acids (butyric, propionic and acetic acids) and alcohols were determined using gas chromatography (GC-14B, Shimadzu, Tokyo, Japan) equipped with a flame ionization detector (FID). Samples were injected into a $15 \mathrm{~m}$ long capillary column with an internal diameter of $0.53 \mathrm{~mm}$. Nitrogen was used as the carrier gas with a flow rate of $20 \mathrm{~mL} / \mathrm{min}$. The temperature of injector and detector was set at 220 and $230{ }^{\circ} \mathrm{C}$, respectively. The oven temperature was initially set at $110^{\circ} \mathrm{C}$, increased from 110 to $200^{\circ} \mathrm{C}$ at a rate of $8^{\circ} \mathrm{C} / \mathrm{min}$ and held at $200{ }^{\circ} \mathrm{C}$ for $5 \mathrm{~min}$. Liquid samples were centrifuged (4000 rpm for $10 \mathrm{~min}$ ) and filtered $(0.45 \mu \mathrm{m}$ membrane) prior to being injected into GC for analysis. Biomass productivity was calculated from the total volume of wastewater used and the total weight of biomass produced in the process after each retention time. The $\mathrm{pH}$ was measured using a digital $\mathrm{pH}$-meter (Metrohm 620). Centrifugation was carried out in a thermostatic Sigma centrifuge (B. Braun, Melsungen, Germany). Since the properties of the wastewater varied at each collection time, representative sample was used for the analyses of the organic compounds, functional group, total nitrogen (TN) and organic acids present in the wastewater. All experiments were conducted in triplicate and mean value reported.

\section{RESULTS AND DISCUSSION}

Identification of the bacterium

The isolate was a non-motile, gram negative, oval rod, $0.25 \mu \mathrm{m}$ wide and $1.50 \mu \mathrm{m}$ long and reproducing by binary fission, internal photosynthesis membrane appeared as lamella. After growth under anaerobic photoheterotrophic conditions, cell suspensions were red and the absorption spectra of living cells suspension showed maxima at $370,570,800,827$ and 852 as shown in Fig.1. The two main peaks at 800 and $850 \mathrm{~nm}$, which are closely related to bacteriochlorophyll $a$ and $b$ (characteristics of photobacteria pigment) as well as carotenoid, are characteristics of PNSB (Madigan et al., 2000). By GC-FAME (Gas chromatography of fatty acid methyl ester) analysis the PNSB isolate was identified as being closely related to Rhodobacter sphaeroides strains with similarity indices of $0.85 \pm 0.05$. This also identifies the isolate as Rhodobacter sphaeroides (Imhoff and Trüper, 198प] Yegani et al., 2005) and it is named Rhodobacter spheroides z08. The isolate grew with organic compounds or thiosulphate in minimal/basal medium with either $\left(\mathrm{NH}_{4}\right)_{2} \mathrm{SO}_{4}$ or $\mathrm{NaNO}_{3}$ as a nitrogen source anaerobically or microaerobically in the light.

\section{Wastewater}

The results of characterization of pharmaceutical wastewater are shown in Tables 1 and 2. According to Table1, the wastewater contains recalcitrant organic compounds such as octadecane, heptacosane and octacosane which are resistant to biodegradation, also compounds like benzothiazole and enzenepropanamine are all toxic and lethal in nature. These identifications were made by GC-MS spectrometry and it is supported by GC-FTIR where three peaks were evident at $1304 \mathrm{~cm}^{-1}$ and $1600-1300 \mathrm{~cm}^{-1}$ (Fig. 2), again suggesting the presence of aliphatic amino salts and aromatic compounds respectively. All these compounds are resistant to biodegradation and accumulate in the environment with a resultant negative effect on the food web. Table 2 also shows that the wastewater is high in COD than BOD, hence low value of BOD to COD ratio $(0.02)$. This again depicts that the wastewater contains high level of non biodegradable organic substances (Bitton, 2005; Banu et. al, 2007) and difficult to treat with conventional biological 
Int. J. Environ. Sci. Tech., 7 (1), 165-174, Winter 2010

Table 1: List of organic compounds tentatively identified in the pharmaceutical wastewater

\begin{tabular}{|c|c|c|c|c|}
\hline Peak No. & Name of compound & $\mathrm{t}_{\mathrm{R}(\min )}$ & Molecular ion peak (m/z) & Fragment ion $(\mathrm{m} / \mathrm{z})$ \\
\hline 1 & Benzenamine & 15.082 & 121 & 120 \\
\hline 2 & Benzothiazole & 24.818 & 181 & 181 \\
\hline 3 & $\begin{array}{l}\text { 1,2-Benzenedicarboxylic acid 1-Butanamine } \\
\text { Benzenepropanamine }\end{array}$ & 31.315 & 278 & 149 \\
\hline 4 & Desmethyldoxepin & 34.082 & 101 & 44 \\
\hline 5 & Methylpent-4-enylamine & 36.262 & 149 & 44 \\
\hline 6 & Nitro-L-arginine & 38.066 & 265 & 44 \\
\hline 7 & 1-Octaecanamine & 38.388 & 99 & 44 \\
\hline 8 & Octadecane & 39.414 & 219 & 44 \\
\hline 9 & Heptacosane & 40.517 & 283 & 44 \\
\hline 10 & Octacosane & 41.760 & 254 & 57 \\
\hline 11 & & 43.144 & 380 & 57 \\
\hline 12 & & 44.702 & 394 & 57 \\
\hline
\end{tabular}

Table 2: Characteristics of the untreated and treated pharmaceutical wastewater (all in mg/L except $\mathrm{pH}$ )

\begin{tabular}{lrr}
\hline Physicochemical & Untreated & Treated \\
\hline $\mathrm{pH}$ & & $7.6 \pm 0.3$ \\
CODcr & $6.6 \pm 0.2$ & $1,526.0 \pm 23$ \\
Total suspended solids & $8,480.0 \pm 932$ & $170.0 \pm 1.6$ \\
Total dissolved solids & $425.0 \pm 2.3$ & $360.0 \pm 1.2$ \\
Total nitrogen & $1,600.0 \pm 1.1$ & $21.5 \pm 0.6$ \\
$\mathrm{BOD} 5$ & $533.7 \pm 0.9$ & $26.0 \pm 0.2$ \\
$\mathrm{Zn}$ & $146.7 \pm 0.3$ & 0.033 .0 \\
$\mathrm{Cd}$ & 0.056 .0 & $\mathrm{ND}$ \\
$\mathrm{Pb}$ & $\mathrm{ND}$ & $\mathrm{ND}$ \\
$\mathrm{Iron}$ & $\mathrm{ND}$ & 0.0223 \\
$\mathrm{Mn}$ & 2.100 & 0.575 \\
$\mathrm{Cu}$ & 0.605 & $\mathrm{ND}$ \\
Acetic acid & 0.022 & $\mathrm{~N} / \mathrm{A}$ \\
Propionic acid & 422.7 & $\mathrm{~N} / \mathrm{A}$ \\
Butyric acid & 201.3 & N/A \\
& 304.5 & \\
\hline
\end{tabular}

treatment methods. These organic compounds found in the pharmaceutical wastewater could be vital part of everyday life, but most of them are of environmental concern because of their toxicity, persistence and tendency for bioaccumulation (Sapana et al., 2008). Some studies have demonstrated inhibition of enzyme activities with different pollutants, including hydrocarbons, heavy metals and surfactants (MartinezTabche et al., 1997; Rodriguez-Fuentes and GoldBouchot, 2000; Hosseini et al, 2007). All these contributed to the difficulty in conventional biological treatment of pharmaceutical wastewater, while being the major consideration for using PNSB to treat this wastewater. The GC-MS fragmentation analyses of the pharmaceutical wastewater after treatment of the optimized wastewater (Table 3) indicate that the PNSB was able to either ameliorate or transform those recalcitrant and xenobiotic materials found in the initial

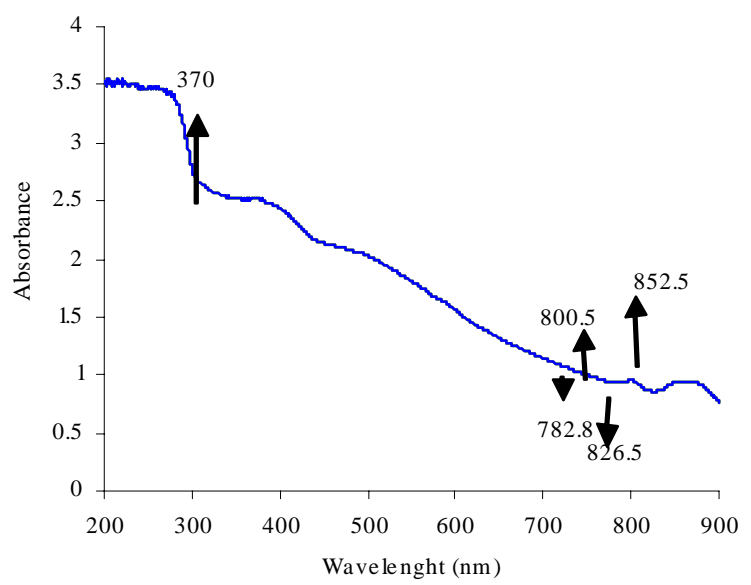

Fig. 1: In vivo spectrum of the isolate (pure culture)

wastewater into some acceptable organic compounds. This finding is in support of Tchobanoglous et al., (2003) which stated that complete biodegradation of recalcitrant organic compounds to harmless end products such as $\mathrm{CO}_{2}$ and $\mathrm{H}_{2} \mathrm{O}$ or methane may not always occur; instead biotransformation to different organic compound is possible. Those recalcitrant and xenobiotic compounds pose problems in conventional wastewater treatment, due to their resistance to biodegradation. This also shows that the PNSB used for this treatment is candidate for bioremediation since it could transform some toxic and recalcitrant organic compounds of natural origin found in the pharmaceutical wastewater. Takeno et al. (2005) treated oil containing sewage wastewater using photosynthetic bacteria; they recorded successful transformation of C 10- C 26 (hydrocarbon) by the photosynthetic bacteria. 
Table 3: List of organic compounds tentatively identified in treated optimized pharmaceutical wastewater

\begin{tabular}{|c|c|c|c|c|}
\hline Peak No. & Name of compound & $t_{R(\min )}$ & Molecular ion peak (m/z) & Fragment ion $(\mathrm{m} / \mathrm{z})$ \\
\hline 1 & 4-methoxybenzene-1,2-diol. & 10.504 & 140 & 140 \\
\hline 2 & Naphthalene & 13.431 & 128 & 128 \\
\hline 3 & 2-Butenoic acid, 2 methyloxy-3methyl ester. & 15.091 & 144 & 43 \\
\hline 4 & 1-2Benzenedicarboxylic acid & 21.946 & 148 & 142 \\
\hline
\end{tabular}

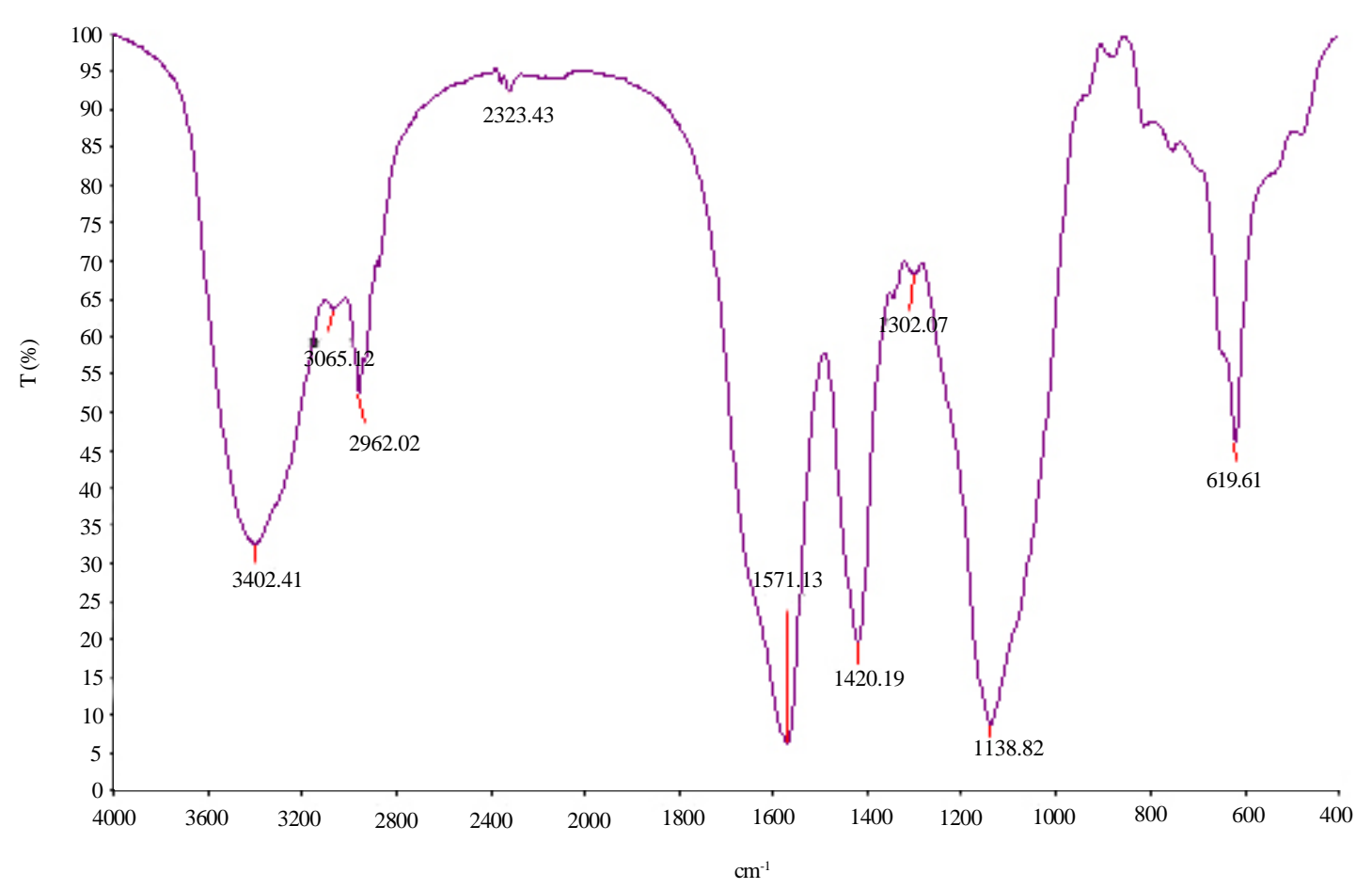

Fig. 2: GC-FTIR spectra of the pharmaceutical untreated wastewater (Fluka library supplied by Perkin-Elmer)

\section{Effects of nitrogen source}

The test water sample has a TN value of about $530 \mathrm{mg} / \mathrm{L}$ (about $0.05 \%$ nitrogen by the weight of the BOD) which did not conform with the biological wastewater treatment of carbon to nitrogen ratio of $5 \%$ nitrogen by the weight of the BOD (Kakabadse, 1979) bearing in mind the load of recalcitrant organic pollutants. Hence, the need for additional nutrients in the form of either $\left(\mathrm{NH}_{4}\right)_{2} \mathrm{SO}_{4}$ or $\mathrm{NaNO}_{3}$. Fig. 3a shows that $\left(\mathrm{NH}_{4}\right)_{2} \mathrm{SO}_{4}$ produced the highest dry cell weight ( $592.3 \mathrm{mg} / \mathrm{L})$ at $4000 \mathrm{mg} / \mathrm{L}$ against $\mathrm{NaNO}_{3}$ with (318.2 mg/L) at the same concentration. Ammonium being the best nutrient was tried further at higher concentrations (Fig. 3b); it gave maximum growth of $672.0 \mathrm{mg} / \mathrm{L} \mathrm{DCW}$ at $5000 \mathrm{mg} / \mathrm{L}$ while further increment retards the growth. Therefore, in order to treat this pharmaceutical wastewater, additional nutrients need to be added to the wastewater to stimulate increase in the growth of the microbes. This procedure is in accordance with the methods which have been commonly used in wastewater treatment (Kakabadse, 1979; Tchobanoglous et al., 2003). This experiment also confirmed that the isolate can utilize either form of nitrogen source (Kantachote et al., 2005). 


\section{Effects of yeast extract}

The addition of yeast extract on ammonium supplemented wastewater further increased the cell growth of the PNSB from OD660 1.03 - 1.502 in the pharmaceutical wastewater test medium. It recorded $0.997 \mathrm{~g} / \mathrm{L} \mathrm{DCW}$ at $1.0 \mathrm{~g} / \mathrm{L}$ concentration. This cultivation was carried out over $96 \mathrm{~h}$ under microaerobic light conditions. High concentration had no significant effect (Fig.4). Although yeast extract contain many B vitamins, it may also act as a source of protein and its use depends on the economic evaluation of the process.

\section{Effects of light intensity}

In order to optimize the treatment conditions, the incident light intensity were varied between 500 to 8000 lumens. The best growth was observed at 6000lx (Fig. 5) with a COD reduction of about $75 \%$ (initial COD value of 2500 to final value of $604 \mathrm{mg} / \mathrm{L}$, respectively) and the cell growth was $820.5 \mathrm{mg} / \mathrm{L}$ DCW. While a temperature range of $20-30{ }^{\circ} \mathrm{C}$ depending on the ambient temperature was maintained. This finding could be attributed to the fact that the PNSB thrives better in an intense light.

\section{Optimization of wastewater treatment conditions}

Fig. 6 shows the experiment carried out to infer the effective retention time for the treatment. The isolate grew up to $377.4 \mathrm{mg} / \mathrm{L}$ in SW in $5 \mathrm{~d}$ and almost double the amount in SOW $(688.3 \mathrm{mg} / \mathrm{L})$ at the same $5 \mathrm{~d}$ retention (Fig. 6a). Also Fig. 6b shows that the COD reduction was higher in SOW at 5d than SW (64.8 and $43.0 \%$, respectively), although at $7 \mathrm{~d}$, the COD and dry cell weight were slightly higher than at $5 d$, but $5 d$ was
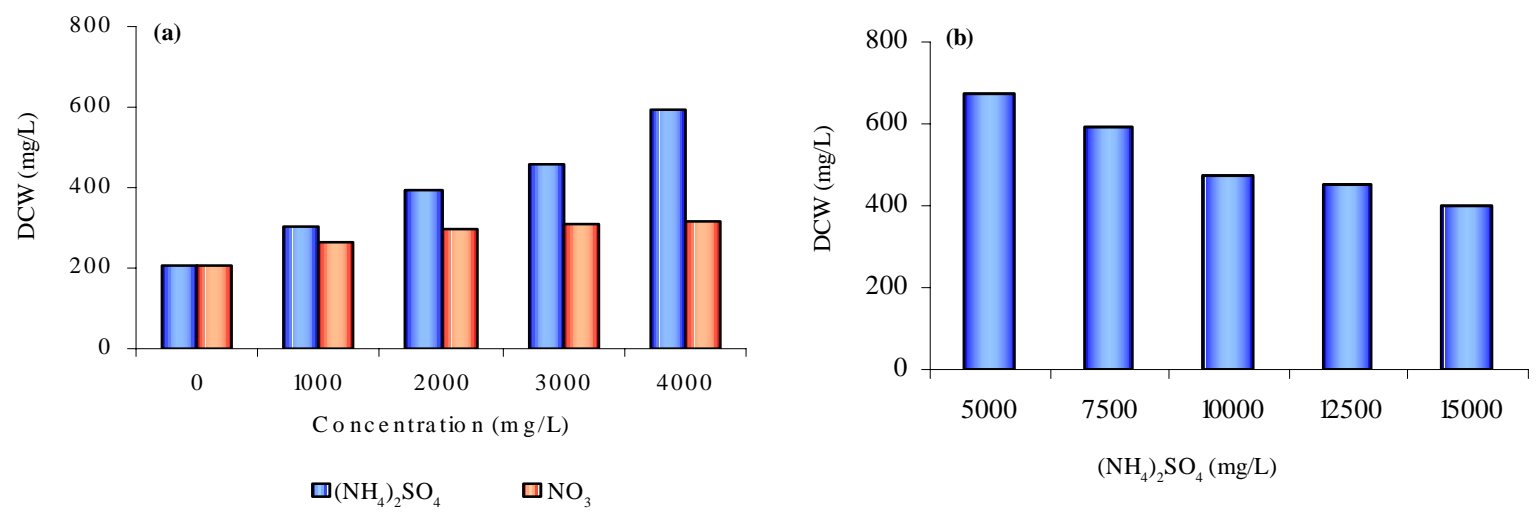

Fig. 3: Effect of nitrogen sources and their concentrations on the growth of the PNSB in pharmaceutical wastewater under microaerobic light conditions for $72 \mathrm{~h}$; (a) Source of nitrogen; (b) Added $\left(\mathrm{NH}_{4}\right)_{2} \mathrm{SO}_{4}$ on bacterial growth

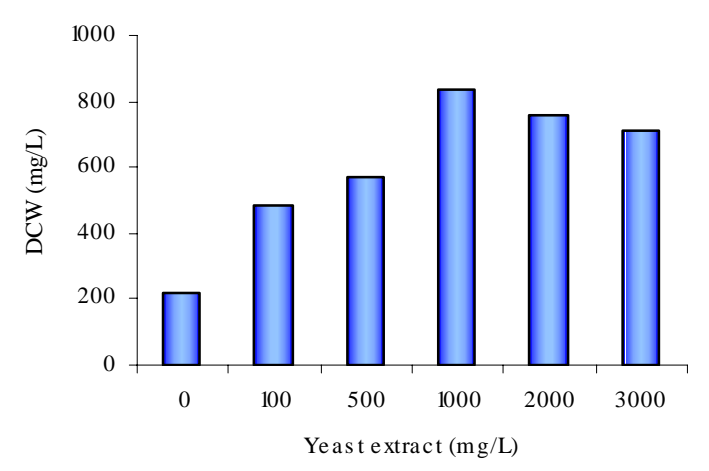

Fig. 4: Effect of added yeast extract and the concentration on the growth of PNSB in pharmaceutical wastewater under microaerobic condition for $72 \mathrm{~h}$ with $\left(\mathrm{NH}_{4}\right)_{2} \mathrm{SO}_{4}=5 \mathrm{~g} / \mathrm{L}$ as base control

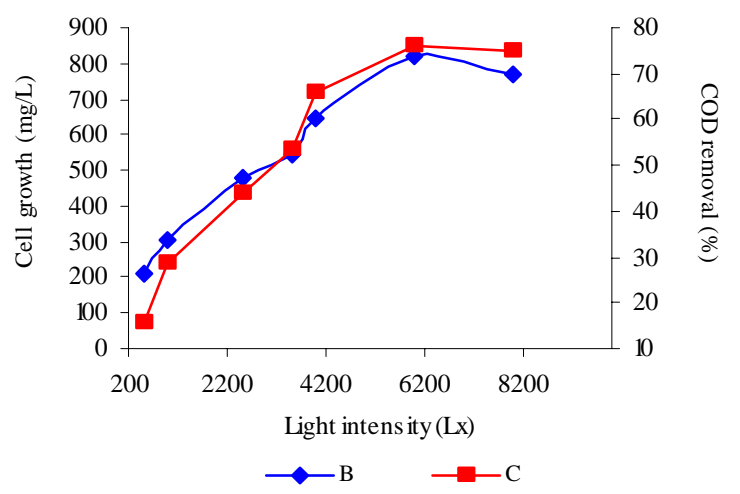

Fig. 5: Effect of light intensity variation on \% COD removal and cell growth $(\mathrm{mg} / \mathrm{L}) . \mathrm{C}=\%$ COD removal, B = Cell growth 
chosen as the optimal retention time for the treatment for economic reasons. The SW with lower COD reduction could be attributed to the inhibition of the cell activity by the recalcitrant pollutants in the wastewater (Table 1), while the sharp reduction of COD in the SOW with inoculums shows that the bacteria activity was increased with additional nutrient hence able to metabolize most of the pollutants faster before the onset of inhibition. There was no COD reduction or cell growth in SOW without inoculation which indicates that no mineralization of pollutants occurred by photo oxidation as COD is the amount of oxygen necessary to oxidize both the organic and inorganic matters to $\mathrm{CO}_{2}, \mathrm{H}_{2} \mathrm{O}$ and $\mathrm{NH}_{3}$ (Bitton, 2005).

The conditions chosen for the treatment of the pharmaceutical wastewater were therefore as follows: supplemented wastewater was with $0.5 \%$ ammonium sulphate and $0.1 \%$ yeast extract with a final $\mathrm{pH}$ of 6.67.0 , incubation was without shaking at $20-30{ }^{\circ} \mathrm{C}$ for $5 \mathrm{~d}$ with an incident light intensity of $6000 \mathrm{~lx}$ using fluorescent compact light also the non-supplemented wastewater. The choice of fluorescent compact lamp for illumination of the PBR was as a result that greater proportion of its power is converted to usable light while smaller proportion is converted to heat as against incandescent lamp which is heat driven and energy draining lamp. Although the initial cost of fluorescent lamp is higher than the incandescent lamp but fluorescent's longer life reduces lamp replacement cost. Typically a fluorescent lamp will last between 10 - 20 times as long as an equivalent incandescent lamp when operated several hours at a time. Therefore, the higher initial cost of a fluorescent lamp is usually more than compensated for by lower energy consumption over its life.

The growth kinetics of the PNSB in batch culture (data not shown), depict that the bacteria maintained speedy growth after $19 \mathrm{~h}$ of cultivation and reached saturation after $5 \mathrm{~d}$. From the result, the specific growth rate was calculated as $0.015 \mathrm{~h}^{-1}$ and $0.011 \mathrm{~h}^{-1}$ for SOW and SW, respectively. While the process productivity based on the five days optimal growth is $0.082 \mathrm{~g} / \mathrm{L} /$ day with a biomass yield of $12.8 \%$ for the optimized wastewater based on the chemical oxygen demand.

The protein content of the culture after treatment in both the supplemented and non-supplemented wastewater is well above the required protein content for it to be acceptable as a protein source for either fish feed or animal feed (Howard, 1987). Therefore, there is a great potential for the culture to be used as a SCP. However, the process productivity was low $(0.082 \mathrm{~g} / \mathrm{L} /$ day). Photosynthetic bacteria typically have lower process productivity than heterotrophic bacteria because the cell densities achieved are low (Kantachote et al., 2005). As for the yield, normal heterotrophs growing aerobically could convert $50 \%$ of organic carbon into biomass, whereas with anaerobic conditions only $5 \%$ is converted into biomass (Speece, 1983). For this microaerobic condition the yield is about $12 \%$ which is much favorable than complete anaerobic condition. Also, in this present study, the bacteria did not thrive well in a complete anaerobic light condition, for instance, after about 2 weeks cultivation anaerobically, its optical density was $\left(\mathrm{OD}_{660}=0.442 \pm\right.$ $0.0014)$. Whereas, at microaerobic light, it recorded greater optical density values in less than 2 weeks of
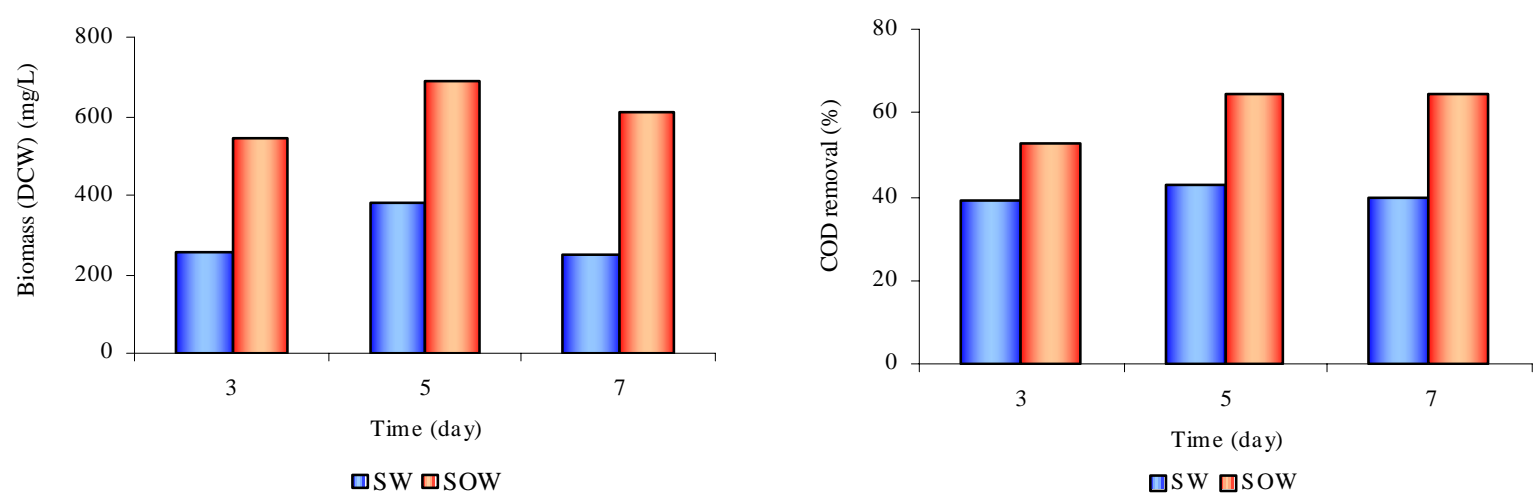

Fig. 6: Cell growth and COD removal as a function of time (at 3500lx, initial COD $=2500 \mathrm{mg} / \mathrm{L}$ ); (a) Biomass in $\mathrm{mg} / \mathrm{L}$ DCW; (b) $\%$ COD Removal; SW = non-supplemented wastewater; SOW = supplemented wastewater; $\left(\mathrm{NH}_{4}\right)_{2} \mathrm{SO}_{4}=5 \mathrm{~g} / \mathrm{L}$ and $\mathrm{YE}=1 \mathrm{~g} / \mathrm{L})$ 
cultivation $\left(\mathrm{OD}_{660}=1.234 \pm 0.0020\right)$. This suggested that the isolated PNSB could thrive better in microaerobic light than anaerobic light condition.

\section{CONCLUSION}

Better waste management will lead to other environmental benefits such as reduction of surface water and groundwater contamination and transformation of organic waste into high-quality manure. Therefore, the treatment procedure could be adopted by the chemical/pharmaceutical industries as interim measure in cubing their pollution problem particularly in most developing countries with abundant sunlight. Wild strain PNSB that is Rhodobacter spheroides $\mathrm{z} 08$ has proven to be effective in ameliorating hazardous pollutants found in pharmaceutical wastewater with over $80 \%$ COD reduction and has the potential to improve the treatment process without any considerable increase in cost. It may also be harvested and find use as a SCP. However, further investigation must be carried out to ensure that the produced biomass is innocuous before its use as a SCP; otherwise, the best option is to use the biomass for energy production. Further work is needed to critically ascertain if the isolate is a toxic tolerant PNSB.

\section{ACKNOWLEDGEMENTS}

The authors thank the financial supports from National Natural Science Foundation of China (50978072) and Chinese Ministry of Science and Technology (2008ZX07421-003).

\section{REFERENCES}

APHA, (1992). Standard Methods for the Examination of Water and Wastewater, $18^{\text {th }}$ Ed. American public Health Association Washington, DC. USA.

Banerjee, S.; Azad, S. A.; Vikineswary, S.; Selvaraj O. S.; Mukherjee, T. K.; (2000). Phototrophic bacteria as fish feed supplements. Asian-Aust. J. Anim. Sci., 13 (7), 991994 (4 pages). (in-Chinese)

Banu J. R.; Kallappan S.; Yeom I. T.; 2007. Treatment of domestic wastewater using upflow anaerobic sludge blanket reactor. Int. J. Environ. Sci. Tech., 4 (3), 363-370 (8 pages).

Bertling, K.; Hurse, T. J.; Kappler, U.; Bakie, A. D., (2006). Cultivation of photosynthetic bacteria using Vertical-Cavity Surface-Emitting Lasers. UQ ITEE Innovation Expo.

Bitton, G., (2005). Wastewater Microbiology, $3^{\text {rd }}$ Ed. 55-72, 213-222, 502-518. Wiley-Liss Pub, N.Y.

Cheremisinoff, N. P.; (1996). Biotechnology for Waste and Wastewater Treatment. Noyes Publishers, Westwood, New Jersey, USA. 116.
Choorit, W.; Thanahoset, P.; Thongpradistha, J.; Sasaki, K.; Noparatnaraporn, N.; (2002). Identification and cultivation of photosynthetic bacteria in wastewater from a concentrated latex processing factory. Biotechnol. Lett. 24 (13), 1055-1058 (4 pages).

Cokgor, U. E.; Karahan, O.; Dogruel, S.; Orlon, D., (2004). Biological treatability of raw and ozonated penicillin formulated effluent. J. Hazard. Mater., 116 (1-2), 159-166 (8 pages).

Eloi, G.; Manuel, O.; Isidre, G.; Montserra, L.; Jordi, B., (1992). Isolation and characterization of a recombination defectivedependent bacteriophage of Rhodobacter sphaeroides. Curr. Microbiol., 24 (3), 151-157 (7 pages).

Galley, A. G.; Forster, C. F.; Stafford, D. A., (1977). Treatment of Industrial Effluent. Hodder and Stoughton. London, UK.

Getha, K.; Chong, V. C.; Vikineswary, S., (1998). Potential use of the phototrophic bacteria, Rhodopseudomonas Palustris as an aqua-culture feed. Asian Fish. Sci., 10, 223-232 (10 pages).

Holt, J. G.; Krieg, N. R.; Sneath, P. H. A.; Staley, J. T.; Williams, S. T., (1994). Bergey's manual of determinative bacteriology. $9^{\text {th. }}$ Ed., Baltimore; the Williams Wilkins Co., 787.

Hosseini F.; Malekzadeh F.; Amirmozafari N.; Ghaemi N.; 2007. Biodegradation of anionic surfactant by isolated bacteria from activated sludge. Int. J. Environ. Sci. Tech., 4 (1), 127-132 (6 pages).

Howard, G., (1987). The world of microbes. The Benjamin Cummings Publishing, Inc. USA.

Huseyin, T.; Oken, B.; Selale, S. A.; Tolga, H. B.; Ceribas, I. B.; Sarin, F. D.; Filiz, B. D.; Ulku, Y., (2006). Use of fenton oxidation to improve the biodegradability of pharmaceutical wastewater. J. Hazard. Mater., 136 (2), 258-265 (8 pages).

Imhoff, J. F.; Trüper, H. G., (1989). Purple nonsulfur bacteria. In: Staley, J. T. (Ed.), Bergey's manual of systematic bacteriology. Baltimore, Williams and Wilkins. 3, $9^{\text {th. }}$ Ed., 1904-1910.

Kakabadse, G., (1979). Chemistry of effluent treatment. Appl. Sci. Publishers Ltd. Manchester, UK. 25-59.

Kantachote, D.; Salwa, T.; Kamontam, U., (2005). The potential use of anoxygenic photosynthetic bacteria for treating latex rubber sheet wastewater. Electron. J. Biotech., 8 (3), 314-323 (10 pages).

Kasomu I. B. M.; Obst M., (2009). The influence of picocyanobacterial photosynthesis on calcite precipitation. Int. J. Environ. Sci. Tech., 6 (4), 557-562 (6 pages).

Lorrungruang, C.; Martthong, J.; Sasaki, K.; Noparatnaraporn N., (2006). Selection of photosynthetic bacterium Rhodobacter Sphaeroides $14 \mathrm{~F}$ for polyhydroxyalkanoate production with two-stage aerobic dark cultivation. J. Biosci. Bioeng., 102 (2), 128-131 (4 pages).

Madigan, M. T.; Jung, D. O.; Woese, C. R.; Achenbach, L. A.; (2000). Rhodoferax antarcticus sp. nov., a moderately psychrophilic purple nonsulfur bacterium isolated from an Antarctic microbial mat. Arch. Microbiol., 173 (4), 269277 (9 pages).

Martínez-Tabche, L.; Ramirez-Mora, B.; Germán-Fa, C.; GalarCastelán, I.; Madrigal-Ortiz, M.; Ulloa-González, V.; Orozco-Flores, M.; (1997). Toxic effects of sodium dodecylbenzensulfonato, lead, petroleum and their mixtures on the activity of acetylcholinesterase of Moina macrocopa in vitro. Environ. Toxicol. Water Qual., 12, (3), 211-215 (5 pages). 
Myung, K. K.; Choi, K. M.; Yin, C. R.; Lee, K. Y.; Im, W. T.; Lim, J. H.; Lee, S. T., (2004). Odorous swine wastewater treatment by purple non-sulfur bacteria, Rhodopseupdomonas Pulustris, isolated from eutrophicated ponds. Biotech Lett., 26 (10), 819-822 (4 pages).

Okubo, Y.; Hiroyuki, F.; Akira, H., (2006). Characterization of phototrophic purple non-sulfur Bacteria forming colored microbial mats in a swine wastewater Ditch. Appl. Environ. Microb., 12 (9), 6225-6233 (9 pages).

Prasertsan, P.; Jaturapornpipat, M.; Sirpatana, C., (1997). Utilization and treatment of tuna condensate by photosynthetic bacteria. Pure Appl. Chem., 69 (11), 24382445 (8 pages).

Ren, N.; Chen, Z.; Wang, A.; Zhang, Z. P.; Yue, S., (2008). A novel application of TPAD-MBR system to the pilot treatment of chemical synthesis-based pharmaceutical wastewater. Water Res., 42, (13), 3385-3392 (8 pages).

Rodriguez Fuentes, G.; Gold Bouchot, G., (2000). Environmental monitoring using acetyl cholinesterase inhibition in vitro: A case study in two Mexican lagoons. Mar. Environ. Res., 50 (1-5), 357-360 (4 pages).

Sapana, S.; Sujata, B.; Amruta, T.; Kalal, K.; Phalgune, U. D.; Deshpande, N. R., (2008). GC-MS Study of hydrocarbons- A
Renewable Biofuel with high calorific value from aerial roots of ficus Benghalensis Linn. Electron. J. Environ., Agri. Food Chem., 7 (14), 2743-2748 (6 pages).

Sasser, M., (1990). Identification of bacteria by gas chromatography of cellular Fatty acids. MIDI technical note 101. MIDI, Newark, Del. USA.

Speece, R. E., (1983). Anaerobic biotechnology for industrial Waste treatment. Environ. Sci. Tech., 17 (9), 416-427 (12 pages).

Takeno, K.; Yamaoka, Y.; Sasaki, K., (2005). Treatment of oil- containing sewage wastewater using immobilized photosynthetic bacteria. W. J. of Microb. Biotech., 21 (89), 1385-1391 (7 pages).

Tchobanoglous, G.; Franklin, L. B.; Stensel, D. H., (2003). Wastewater Engineering, Treatment and Reuse. $4^{\text {th. }}$ Ed. Metcalf and Eddy, Inc. NY. USA.

Yegani, R.; Satoshi, Y.; Kazunori, M.; Tomoshisa, K; Shigeo, K., (2005). Improvement of growth stability of photosynthetic bacterium Rhodobacter capsulatus. J. Biosci Bioeng., 10 (6), 672-677 (6 pages).

\section{AUTHOR (S) BIOSKETCHES}

Madukasi, E. I., Research officer, The Federal Institute of Industrial Research, Oshodi, Lagos Nigeria and a Ph.D. Candidate, School of Municipal and Environmental Engineering, Harbin Institute of Technology, China. Email: madify2002@yahoo.com

Dai, X., M.Sc. Student, School of Municipal and Environmental Engineering, Harbin Institute of Technology, China. Email:daixioa@sina.com

He, C., M.Sc. Student, School of Municipal and Environmental Engineering, Harbin Institute of Technology, China.

Email:Chunhua85@sina.com

Zhou, J., M.Sc. Student, School of Municipal and Environmental Engineering, Harbin Institute of Technology, China. Email: zhoujingjing1234_200@126.com 